\title{
A fecundidade das uniões homoafetivas
}

\section{The fertility of homoaffective unions}

\author{
Emerson Sbardelotti* \\ João Melo e Silva Junior**
}

Recebido: 20/06/2019. Aprovado: 26/07/2019.

Resumo: O aumento de cristãos/ãs que assumem publicamente uma união entre pessoas do mesmo sexo, torna iminente que a lgreja faça uma profunda reflexão sobre os caminhos de amadurecimento e crescimento na fé para essas pessoas e suscite na comunidade cristã um ambiente de acolhimento e integração que, ao mesmo tempo, se afaste de qualquer tipo de relativismo acerca das exigências do Evangelho. A partir de uma aproximação dos conceitos de sexualidade, castidade e celibato, propomos uma reflexão sobre o amadurecimento afetivo de uma união homoafetiva e, a partir daí, enfrentamos a problemática moral da culpabilidade da atividade homossexual. Depois, tentamos apresentar uma distinção entre união homoafetiva e matrimônio, e seus papéis sociais. Por fim, queremos levantar a pergunta acerca de uma possível "fecundidade" presente nas uniões entre pessoas do mesmo sexo, tendo como ponto de partida a categoria "fecundidade alargada", utilizada pelo papa Francisco em Amoris Laetitia n.178-184.

Palavras-chave: Fecundidade alargada. Amoris Laetitia. Uniões homoafetivas. Homossexualidade.

Abstract: The increase of Christians who publicly assume a union between persons of the same sex makes it imminent for the Church to reflect deeply on the paths of maturity and growth in the faith for these people and to arouse in the Christian community an environment of welcome and integration which, at the same time, move away from any kind of relativism about the requirements of the Gospel. From an approximation of the concepts of sexuality, chastity and celibacy, we propose a reflection on the affective maturation of a homoaffective

* Doutorando em Teologia (PUC-SP, São Paulo). Mestre em Teologia (PUC-SP, São Paulo, 2016). Graduado em Turismo (Faculdade de Turismo de Guarapari, Guarapari, 1996). Graduado em Licenciatura Plena (Centro Universitário São Camilo, Batatais, 2010). Graduado em Teologia (Instituto de Filosofia e Teologia da Arquidiocese de Vitória, Vitória, 2012). Especialista em Gestão Ambiental e Sustentabilidade (Instituto Superior de Educação de Afonso Cláudio - ISEAC, Afonso Cláudio, 2014).

E-mail: prof.poeta.emerson@gmail.com

** Graduado em Filosofia (Centro Universitário Assunção, São Paulo, 2014).

E-mail: joaomelo10@hotmail.com 
union and, from there, we face the moral problematic of the culpability of the homosexual activity. Then we try to present a distinction between homoafetive union and marriage, and their social roles. Finally, we want to raise the question of a possible "fruitfulness" present in same-sex unions, starting with the category "expanding fruitfulness", used by Pope Francis in Amoris Laetitia n.178-184.

Keywords: Expanding fruitfulness. Amoris Laetitia. Homoaffective unions. Homosexuality.

\section{Introdução}

Com o significativo aumento de cristãos/ãs que assumem publicamente uma união entre pessoas do mesmo sexo, torna-se iminente que a Igreja faça uma profunda reflexão sobre os caminhos de amadurecimento e crescimento na fé para essas pessoas e suscite na comunidade cristã um ambiente de acolhimento e integração que, ao mesmo tempo, se afaste de qualquer tipo de relativismo acerca das exigências do Evangelho.

Dentre as várias situações familiares chamadas "irregulares", são grandes os dramas e os sofrimentos das pessoas em união homoafetiva que buscam a Deus com sinceridade na Igreja Católica e não encontram acolhida e espaço para participarem ativamente na vida e na missão da Igreja. Com seus próprios desafios, a situação das pessoas em união homoafetiva não ocupou até hoje suficiente lugar na reflexão dos documentos emanados pelo Magistério da Igreja, o que, por vezes, obnubila a expressão da misericórdia divina que não tem limites. Não obstante, os dois últimos sínodos dos bispos sobre a família, "Os desafios pastorais da família no contexto da evangelização" ocorrido em 2014 e "A vocação e a missão da família na Igreja e no mundo contemporâneo" ocorrido em 2015 são, respectivamente, assembleia extraordinária e assembleia ordinária do mesmo sínodo, frutificaram na recente exortação apostólica pós-sinodal do papa Francisco sobre o amor na família, Amoris Laetitia, que oferece elementos propícios para uma reflexão sobre esse assunto. Por essa razão, e por este texto constituir a expressão mais atual da reflexão do episcopado universal, elegemo-lo como fundamento de nossa reflexão. Além dele, queremos alicerçar o nosso artigo em escritos que, em graus distintos, são também expressões recentes do Magistério da Igreja para elucidar como, a partir de tais textos, pode-se aprofundar a questão aqui apresentada.

A partir de uma aproximação dos conceitos de sexualidade, castidade e celibato, propomos uma reflexão sobre o amadurecimento afetivo de uma união homoafetiva e, a partir daí, enfrentamos a problemática 
moral da culpabilidade da atividade homossexual ${ }^{1}$. Depois, tentamos apresentar uma distinção entre união homoafetiva e matrimônio, e seus papéis sociais.

Por fim, queremos levantar a pergunta acerca de uma possível "fecundidade" presente nas uniões entre pessoas do mesmo sexo. Não temos a intenção de propor uma sugestão normativa, mas somente fazer uma investigação, tendo como ponto de partida a categoria "fecundidade alargada", utilizada pelo papa Francisco na Amoris Laetitia n.178-184. Faz-se mister afirmar desde o início que o pontífice não relaciona nem aplica a expressão "fecundidade alargada" às uniões homoafetivas. Essa aproximação que se delineará ao longo do texto é nossa. O que ele afirma categoricamente é que "cada pessoa, independentemente da própria orientação sexual, deve ser respeitada na sua dignidade e acolhida com respeito, procurando evitar todo sinal de discriminação injusta e particularmente toda a forma de agressão ou violência"².

O pontificado do papa Francisco nos orienta a estarmos atentos aos sinais dos tempos que nos ajudam a discernir a vontade de Deus, e também para uma atitude misericordiosa e de constante busca de integração daqueles/as que vivem nas situações mais periféricas da sociedade e do mundo cristão. São essas atitudes que inspiram a nossa reflexão que, portanto, está situada a partir do ensinamento oficial da Igreja presente

\footnotetext{
A Congregação para a Doutrina da Fé faz uma distinção entre a condição ou tendência homossexual, de um lado, e, do outro, os atos homossexuais. Cf. CONGREGAÇÃO PARAA DOUTRINA DA FÉ. Carta aos bispos da Igreja Católica sobre o atendimento pastoral das pessoas homossexuais, 1986. n. 3. Disponível em: <http://www.vatican. va/roman_curia/congregations/cfaith/documents/rc_con_cfaith_doc_19861001_homosexual-persons_po.html>. Acesso em: 02 jul. 2019. Sendo assim, expressões como "condição homossexual", "pessoas homossexuais", "inclinação homossexual", "orientação sexual homossexual", entre outras, presentes nos textos católicos, indicam a orientação sexual homoafetiva. Já o exercício da genitalidade entre pessoas homoafetivas é denominado como "atos homossexuais", "atividades homossexuais", "relações homossexuais", "atos de homossexualidade", etc. Nosso artigo acata essa distinção e alinha-se ao pensamento do jesuíta Vicent Genovesi: "Por não ser escolhida voluntariamente, a orientação sexual da pessoa, quer heterossexual, quer homossexual, não ser por si só assunto para análise ou avaliação moral. [...] Entretanto, surgem realmente questões morais e elas são apropriadas quando as pessoas, sejam elas heterossexuais ou homossexuais, enfrentam escolhas reais para decidir se devem ou não expressar sua orientação sexual em atividade genital específica e sob quais circunstâncias" (GENOVESI, SJ. Vicent. Em busca do amor: moralidade católica e sexualidade humana. São Paulo: Loyola, 2008. p. 249; 252).
}

2 FRANCISCO, papa. Exortação apostólica pós-sinodal Amoris Laetitia (AL), 2016. n. 250. Disponível em: <http://w2.vatican.va/content/francesco/pt/apost_exhortations/ documents/papa-francesco_esortazione-ap_20160319_amoris-laetitia.html>. Acesso em: 02 jul. 2019. 
nos mais recentes textos do Magistério Universal. Nesse sentido, a consideração que este artigo faz sobre as uniões homoafetivas situa-se exclusivamente na perspectiva teológica da moral católica.

Desde já notificamos que algumas expressões e vocábulos utilizados ao longo do nosso texto não são usados por alguns segmentos sociais e por algumas abordagens das ciências modernas porque são considerados impróprios ou ultrapassados para falar da homossexualidade. No entanto, por uma questão metodológica, visto que o presente artigo é alicerçado em documentos e alocuções do Magistério da Igreja Católica, optamos por manter tais expressões, mesmo cientes da problemática que isso pode representar para alguns ${ }^{3}$.

\section{O caminho sinodal e a homossexualidade}

A mensagem cristã no campo da sexualidade e da família tem uma grandeza e uma beleza inegáveis. Não é de hoje que a Igreja pede que a reflexão teológica aprofunde também o assunto da homossexualidade 4 . O primeiro dos dois sínodos dos bispos sobre a família, num relatório preliminar, endossou essa necessidade:

A questão homossexual interpela-nos a uma séria reflexão acerca do modo como elaborar caminhos realistas de crescimento afetivo e de maturidade humana e evangélica, integrando a dimensão sexual ${ }^{5}$.

Mesmo sendo apenas consultivos, os sínodos dos bispos trouxeram indicações muito relevantes sobre a situação eclesial, os consensos e as divergências existentes entre os bispos, que são muito importantes para o discernimento do papa.

3 A expressão "LGBT", por exemplo, foi usada em um texto da Santa Sé uma única vez para designar jovens LBGTQ+ em XV ASSEMBLEIA GERAL ORDINÁRIA DO SíNODO DOS BISPOS. Instrumentum Laboris, 2018. n. 197. Disponível em: <http://www. vatican.va/roman_curia/synod/documents/rc_synod_doc_20180508_instrumentum-xvassemblea-giovani_po.html>. Acesso em: 02 jul. 2019.

4 Carta aos bispos da Igreja Católica sobre o atendimento pastoral das pessoas homossexuais, n. 17.

5 III ASSEMBLEIA GERAL EXTRAORDINÁRIA DO SÍNODO DOS BISPOS. Relatio post disceptationem, 2014. n. 51. Disponível em: <http://www.vatican.va/roman_curia/ synod/documents/rc_synod_doc_20141013_erdo-synod_po.html>. Acesso em: 02 jul. 2019. 
Diante da variedade inumerável de situações familiares concretas, o papa alertou que não se deveria esperar dos sínodos ou da exortação pós-sinodal uma nova normativa geral de tipo canônico, aplicável a todos os casos. $\mathrm{Na}$ verdade, os sínodos e a exortação tinham a missão de dar um novo encorajamento a um responsável discernimento pessoal e pastoral de cada caso em particular ${ }^{6}$.

Dito de outra maneira, o discernimento e as respostas aos desafios das situações familiares não são tarefas exclusivas do Magistério Universal da Igreja. "As diferentes comunidades é que deverão elaborar propostas mais práticas e eficazes, que tenham em conta tanto a doutrina da Igreja como as necessidades e desafios locais" . Além disso, deve-se levar em conta que os/as fiéis "muitas vezes respondem o melhor que podem ao Evangelho no meio dos seus limites, e são capazes de realizar o seu próprio discernimento perante situações onde se rompem todos os esquemas"8.

\section{Sexualidade e castidade}

A sexualidade é uma característica intrínseca à condição humana desejada por Deus na ordem da criação que nos dota de capacidade relacional. Com efeito,

a sexualidade afeta todos os aspectos da pessoa humana, na unidade do seu corpo e da sua alma. Diz respeito particularmente à afetividade, à capacidade de amar e de procriar, e, de um modo mais geral, à aptidão para criar laços de comunhão com outrem?

A compreensão de sexualidade não pode ser reduzida a genitalidade, isto é, a atividades sexuais.

A castidade, por sua vez é descrita e, em certo sentido, definida como "a integração conseguida da sexualidade na pessoa e daí a unidade interior do homem no seu ser corporal e espiritual" ${ }^{\prime \prime}$. Trata-se de uma energia espiritual que orienta e ordena a sexualidade para o dom de si

\footnotetext{
6 Cf. Amoris Laetitia, n. 300.

7 Idem, n. 199.

8 Idem, n. 37.

9 CATECISMO DA IGREJA CATÓLICA (CaIC), 1991. n. 2332. Disponível em: <http:// www.vatican.va/archive/cathechism_po/index_new/prima-pagina-cic_po.html>. Acesso em: 02 jul. 2019.

10 Idem, n. 2337
} 
que se realiza na vocação específica de cada um ${ }^{11}$. É a virtude de quem cresce, pela graça de Deus e pelo esforço humano, no conhecimento e no autodomínio dos seus afetos, desejos e sentimentos. A virtude da castidade engloba, portanto, a integridade da pessoa e a integralidade da doação. Em essência, a castidade é a expressão da sexualidade orientada para a doação e para o acolhimento do/a outro/a, libertando do egoísmo, tornando as pessoas abertas ao amor e à fecundidade, e fazendo-as mais generosos no dom de si.

Objetivamente, a moral católica ensina que, no que se refere à genitalidade, as pessoas casadas são chamadas a viver a castidade conjugal, isto é, a fidelidade ao cônjuge, enquanto as outras pessoas são chamadas a praticarem a castidade na continência sexual. ${ }^{12}$

\section{O Celibato é um dom de Deus}

O dom do celibato é a capacidade dada por Deus a algumas pessoas de viverem sem a necessidade de manter relações sexuais. A incapacidade de resistir à necessidade de manter relações sexuais é um sinal de que o indivíduo não tem este dom. Dirigindo-se à comunidade de Corinto, São Paulo afirma: "Mas, se não podem conter-se, casem-se..." (1Cor 7,9). Como todo dom, também o do celibato é dado a alguns e não a outros: "Porque quereria que todos os homens fossem como eu mesmo [Paulo era celibatário]; mas cada um tem de Deus o seu próprio dom, um de uma maneira e outro de outra" (1Cor 7,7). De fato, pelas aferições do Apóstolo dos gentios, não parece que todas as pessoas, independentemente de sua orientação sexual, sejam vocacionadas a viver a castidade na condição de celibatárias. Há pessoas que não possuem esse dom.

O Catecismo da Igreja Católica afirma que "as pessoas homossexuais são chamadas à castidade" ${ }^{13}$. Esse chamado não lhes é específico: "as pessoas homossexuais, como os demais cristãos, são chamadas a viver a castidade" 14 . O dever moral postulado pela Igreja convida as pessoas homossexuais a viverem de forma livre a castidade na conti-

11 Cf. SÃO JOÃO PAULO II, papa. Exortação Apostólica Familiaris Consortio (FC), 1981. n. 33. Disponível em: <http://w2.vatican.va/content/john-paul-ii/pt/apost_exhortations/ documents/hf_jp-ii_exh_19811122_familiaris-consortio.html>. Acesso em: 02 jul. 2019.

12 Cf. Catecismo da Igreja Católica, n. 2349.

13 Idem, n. 2359.

14 Carta aos bispos da Igreja Católica sobre o atendimento pastoral das pessoas homossexuais, n. 11 (grifos nossos). 
nência sexual: "Como em toda conversão do mal, graças a tal liberdade, o esforço humano, iluminado e sustentado pela graça de Deus, poderá permitir-lhes evitar a atividade homossexual" "15. Nesse trecho da Carta aos bispos da Igreja Católica sobre o atendimento pastoral das pessoas homossexuais o chamado ao celibato está ilustrado em suas duas condições essenciais: o esforço humano fundado na liberdade e a graça de Deus. O esforço humano refere-se à diligência empreendida pelo indivíduo a partir de suas condições e condicionamentos que influenciam decisivamente na deliberalidade de suas atitudes. A graça de Deus é o auxílio divino que vem em socorro da natureza humana e que age a partir dela. A graça de Deus pressupõe a natureza humana. De fato, não pode haver opção celibatária cristã em que o indivíduo não possua deliberalidade para assumi-la, ou que não seja motivada pelo amor a Deus e ao próximo. Na falta de uma das duas condições, o celibato cristão não é possivel ou não é vivido como um dom, tornando-se um sofrimento e fonte de constante infelicidade. São Paulo exorta "que cada um viva na condição na qual o Senhor o colocou ou em que o Senhor o chamou" (1Cor 7,17). Convém lembrar que o Apóstolo dos gentios também afirma que há pessoas que não possuem o dom de viver a continência sexual (cf. 1Cor 7,7-9). Portanto, o celibato cristão é, em última instância, um dom e não uma consequência automática de uma orientação sexual homossexual.

\section{Amadurecimento afetivo na imperfeição}

Nosso texto quer a partir daqui considerar as pessoas homossexuais que constituíram uma união estável e exclusiva com um/uma único/a parceiro/a do mesmo sexo. No entanto, nossa reflexão não objeta tratar da problemática do reconhecimento civil dessas uniões.

A partir do pressuposto de que o ideal cristão da castidade deve ser proposto a todos/as, independentemente da orientação sexual, "devemos incentivar o amadurecimento duma consciência esclarecida, formada e acompanhada pelo discernimento responsável e sério do pastor, e propor uma confiança cada vez maior na graça" ${ }^{16}$. As uniões estáveis e exclusivas entre pessoas do mesmo sexo, embora em dissonância com as exigências do Evangelho interpretadas à luz da fé católica, são distintas de um tipo

\footnotetext{
15 Ibidem (grifos nossos).

16 Amoris Laetitia, n. 303.
} 
de relação afetiva e/ou sexual descompromissada, promíscua ou até mesmo violenta como a apresentada em Gn 19,1-1117.

De fato,

a consciência pode reconhecer não só que uma situação não corresponde objetivamente à proposta geral do Evangelho, mas reconhecer também, com sinceridade e honestidade, aquilo que, por agora, é a resposta generosa que se pode oferecer a Deus e descobrir com certa segurança moral que esta é a doação que o próprio Deus está a pedir no meio da complexidade concreta dos limites, embora não seja ainda plenamente o ideal objetivo ${ }^{18}$.

Nesse sentido, a orientação da sexualidade para uma expressão mais sóbria de exclusividade e estabilidade está mais próxima do ideal cristão da castidade do que uma atividade sexual promíscua, descompromissada e violenta.

Com efeito, não se deixa de valorizar os elementos construtivos nas situações que não correspondem ao ideal cristão da castidade: "é possível acompanhar com misericórdia e paciência, as possíveis etapas de crescimento das pessoas, que se vão construindo dia após dia" $" 19$.

Essas uniões configuram uma etapa de amadurecimento afetivo na medida em que a afetividade das duas pessoas envolvidas está orientada, de forma estável e mais exclusiva, uma para a outra. "Em todo o caso, lembremo-nos que este discernimento é dinâmico e deve permanecer sempre aberto para novas etapas de crescimento e novas decisões que permitam realizar o ideal de forma mais completa" 20 .

Portanto, uma união estável e exclusiva entre pessoas do mesmo sexo é uma expressão imperfeita, mas significativa, da vivência cristã da castidade e precisa ser assim considerada. A própria exortação apostólica Amoris Laetitia admite que "devemos reconhecer a grande

17 "Lendo-se atentamente o texto, todos os exegetas de hoje em dia estão de acordo em dizer que não é a presumida homossexualidade dos habitantes de Sodoma que provocou o julgamento de Deus, mas a agressão coletiva, o ato gratuito de violência sexual que não respeita o dever de acolhimento do estrangeiro e da hospitalidade" BESSON, Claude. Homossexuais católicos: como sair do impasse. São Paulo: Loyola, 2015. p. 62. Por 'atividade sexual promíscua, descompromissada e violenta' entenda-se relações genitais forçadas (estupro).

18 Idem.

19 Ibidem, n. 308.

20 Ibidem, n. 303. 
variedade de situações familiares que podem fornecer certa regra de vida" ${ }^{21}$. A estabilidade e a exclusividade das uniões entre pessoas do mesmo sexo fornecem certa regra de vida para as pessoas que vivem nessa situação familiar.

Chegados a esse ponto, a questão que se impõe é: uma pessoa cristã que se sente orientada homossexualmente e não tem o dom ou as condições deliberativas de escolha para optar pela vida celibatária, deve ser considerada em pecado mortal caso mantenha relações sexuais com um/uma único/a e exclusivo/a parceiro/a do mesmo sexo com quem encontra apoio mútuo?

\section{"A culpabilidade dos atos homossexuais deve ser julgada com prudência"22}

Há no correto desenvolvimento da tradição da teologia pastoral e da teologia moral católica um princípio geral que

sempre reivindicou a distinção - não a separação nem a oposição entre desordem objetiva e culpa subjetiva. [...] É inteiramente legítimo ter em devida consideração os diferentes fatores e aspectos da pessoa para a ação prática, não só suas intenções e motivações, mas também as diferentes circunstâncias de sua vida, em primeiro lugar todas as causas que podem afetar o seu conhecimento e seu livre arbitrio. E esta situação subjetiva, enquanto nunca pode se transformar em "ordem", visto que é inerente "desordem", pode afetar em graus variados a responsabilidade da pessoa que age. Como é bem sabido, este é um princípio geral que se aplica a toda desordem moral ${ }^{23}$.

Um discernimento honesto da culpabilidade - culpa subjetiva das pessoas que praticam a atividade homossexual - desordem moral objetiva -, há de ter em conta que dentre as "diferentes circunstâncias de sua vida" que podem afetar o "seu livre arbítrio", deve-se considerar também que a condição homossexual não é uma escolha.

$21 \quad$ Ibidem, n. 52.

22 Carta aos bispos da Igreja Católica sobre o atendimento pastoral das pessoas homossexuais, n. 3.

23 CONGREGAÇÃO PARA A DOUTRINA DA FÉ. The Moral Norm Of "Humanae Vitae" And Pastoral Duty, 1989. n. 3. Disponível em: <http://www.vatican.va/roman_curia/congregations/cfaith/documents/rc_con_cfaith_doc_19890216_norma-morale_en.html>. Acesso em: 02 jul. 2019. (grifos negritos e tradução nossa). 
Nesta linha, já São João Paulo II propunha na Exortação Apostólica Familiaris Consortio n. 34, a chamada lei da gradualidade que é retomada pelo papa Francisco:

Não é uma gradualidade da lei, mas uma gradualidade no exercício prudencial dos atos livres em sujeitos que não estão em condições de compreender, apreciar ou praticar plenamente as exigências objetivas da $l e i^{24}$.

Afastando-nos de qualquer posição generalizadora, o papa Francisco em Amoris Laetitia nos diz que "tanto os Pastores como todos os fiéis que acompanham os seus irmãos na fé ou num caminho de abertura a Deus não podem esquecer aquilo que ensina, com muita clareza, o Catecismo da Igreja Católica: 'A imputabilidade e responsabilidade dum ato podem ser diminuidas, e até anuladas, pela ignorância, a inadvertência, a violência, o medo, os hábitos, as afeições desordenadas e outros fatores psíquicos ou sociais" ${ }^{25}$. Se considerarmos ainda que o próprio Catecismo da Igreja Católica afirma sobre a homossexualidade que "a sua gênese psíquica continua em grande parte por explicar"26, isso significa que, para o Catecismo da Igreja Católica a homossexualidade constitui-se também enquanto fator psíquico cuja "gênese psíquica continua em grande parte por explicar" 27 . Com efeito, embora a postura de encarar a homossexualidade como fator de gênese psíquica ainda por explicar destoe das abordagens que ela recebe por parte das ciências modernas $^{28}$, faz-se mister notar que o número 1735 do Catecismo da Igreja

24 Amoris Laetitia, n. 295.

25 FRANCISCO, Papa. Exortação Apostólica Evangelii Gaudium (EG), 2013. n. 44. Disponível em: <https://w2.vatican.va/content/francesco/pt/apost_exhortations/documents/ papa-francesco_esortazione-ap_20131124_evangelii-gaudium.html>. Acesso em: 02 jul. 2019; cf. Catecismo da Igreja Católica, n. 1735; cf. Amoris Laetitia, n. 302 (grifos nossos).

26 Catecismo da Igreja Católica, n. 2357.

27 Ibidem.

28 Já em 1935 Freud dizia que "sem dúvida, a homossexualidade não constitui nenhuma vantagem, mas não é razão para se envergonhar, nenhum vício, nenhuma degradação; não se classifica como doença; nós a consideramos uma variação da função sexual produzida por certo impedimento na evolução sexual" (FREUD, Sigmund. Letter to an American Mother, in RUITEENBEEK, Hendrick (org.). The Problem of Homosexuality in Modern Society, New York: Dutton, 1963. pp.1-2 apud GENOVESI, SJ. Vicent. Em busca do amor: moralidade católica e sexualidade humana. São Paulo: Loyola, 2008. p. 255). No Brasil, o Conselho Federal de Psicologia determinou que "Art. $3^{\circ}$ - os psicólogos não exercerão qualquer ação que favoreça a patologização de comportamentos ou práticas homoeróticas, nem adotarão ação coercitiva tendente 
Católica elenca "fatores psíquicos" como um dos elementos que podem levar à diminuição e até anulação da imputabilidade dum ato cometido. No caso em questão, da atividade sexual homossexual. Ainda o mesmo Catecismo da Igreja Católica afirma que "os atos de homossexualidade são intrinsecamente desordenados" 29 e que a tendência homossexual é "objetivamente desordenada" 30 . De fato, considerar a tendência e os atos de homossexualidade "desordenados", é considerá-los frutos de uma "afeição desordenada". Ora, o número 1735 do Catecismo da Igreja Católica também elenca "afeições desordenadas" como condição que, em certos casos, pode diminuir ou até mesmo anular a culpabilidade. Portanto, se a tendência e os atos de homossexualidade são desordenados ${ }^{31}$ porque resultados de uma afeição desordenada intrínseca, a atividade sexual homossexual, embora desordenada, pode não ser culposa.

De forma ainda mais clara, a Carta aos bispos da Igreja Católica sobre o atendimento pastoral das pessoas homossexuais, n. 11 da Congregação para a Doutrina da Fé assinada pelo então cardeal Joseph Ratzinger ensina:

Alguns afirmam que a tendência homossexual, em certos casos, não é fruto de uma opção deliberada e que a pessoa homossexual não tem outra alternativa, sendo obrigada a se comportar de modo homossexual. Por conseguinte, afirma-se que, em tais casos, ela agiria sem culpa, não sendo realmente livre. A este propósito, é necessário referir-se à sábia tradição moral da Igreja, que alerta para as generalizações no julgamento dos casos individuais. De fato, em determinados casos, podem ter existido

a orientar homossexuais para tratamentos não solicitados" (CONSELHO FEDERAL DE PSICOLOGIA. Resolução CFP $n^{\circ} 001 / 99$ de 22 de março de 1999: Estabelece normas de atuação para os psicólogos em relação à questão da Orientação Sexual, Brasília, 1999. Disponível em: <https://site.cfp.org.br/wp-content/uploads/1999/03/ resolucao1999_1.pdf $>$. Acesso em 02 jul. 2019). Com efeito, "talvez o principal fator que provoca seus problemas emocionais seja o opróbio social, religioso e pessoal que os homossexuais sofrem há tanto tempo, não a homossexualidade em si" (HETTLINGER, Richard. Sex Isn't That Simple: The New Sexuality on Campus, New York: Seabury, 1974, p.147 apud GENOVESI, SJ. Vicent. Em busca do amor: moralidade católica e sexualidade humana. São Paulo: Loyola, 2008, p. 256). Ibidem. Idem, n. 2358.

31 'Se a razão precisa para se referir à orientação homossexual como 'desordem' é que ela se inclina a atos imorais, então toda inclinação que faça isso [...] [com respeito a quaisquer] atos imorais também é desordenada" (MCCORMICK, SJ, Richard. A. The Critical Calling: Reflections on Moral Dilemmas Since Vatican II, Washington: Georgetown Univ. Press, 1989. p. 311 apud GENOVESI, SJ. Vicent. Em busca do amor. moralidade católica e sexualidade humana. São Paulo: Edições Loyola, 2008. p. 251). 
no passado, e podem subsistir ainda, circunstâncias tais que reduzem ou até mesmo eliminam a culpa do indivíduo; outras circunstâncias, ao contrário, podem agravá-la. Em todo caso, deve-se evitar a presunção infundada e humilhante de que o comportamento homossexual das pessoas homossexuais esteja sempre e totalmente submetido à coação e, portanto, seja sem culpa ${ }^{32}$.

Com efeito, não se trata de aprovar a atividade sexual homossexual ${ }^{33}$, visto que tais atos "não podem, em caso algum, ser aprovados" 34 , mas de entender que sua realização não pode ser sempre e automaticamente compreendida como culposa para quem os pratica. Sendo assim, as pessoas homossexuais que estão sujeitas a fortes condicionamentos que lhes impedem o cumprimento do dever moral, mesmo as que vivem em união homoafetiva, "devem ser acolhidas com respeito, compaixão e delicadeza"35. "É preciso evitar juízos que não levam em consideração a complexidade das diversas situações e é necessário prestar atenção ao modo como as pessoas vivem e sofrem por causa da sua condição"36.

Decorre daí que a resposta à indagação que fizemos antes de iniciar o presente tópico sobre se uma pessoa cristã que se sente orientada homossexualmente e não tem o dom ou as condições deliberativas de escolha para optar pela vida celibatária, deve ser considerada em pecado mortal caso mantenha relações sexuais com um/uma único/a e exclusivo/a parceiro/a do mesmo sexo com quem encontra apoio mútuo, é iluminada pela exortação Amoris Laetitia: "Já não é possível dizer que todos os que estão numa situação chamada "irregular" vivem em estado de pecado mortal, privados da graça santificante" 37 . Não há respostas prontas e acabadas, o que há é o apelo ao discernimento e acompanhamento: Um pastor não pode estar satisfeito apenas com a aplicação da lei moral aos

32 Carta aos bispos da Igreja Católica sobre o atendimento pastoral das pessoas homossexuais, n. 11 (grifos nossos).

33 "Aqueles que se encontram em tal condição deveriam, portanto, ser objeto de uma particular solicitude pastoral, para não serem levados a crer que a realização concreta desta tendência nas relações homossexuais seja uma opção meramente aceitável". Carta aos bispos da Igreja Católica sobre o atendimento pastoral das pessoas homossexuais, n. 3. Catecismo da Igreja Católica, n. 2357.

35 Idem, n. 2358.

36 Amoris Laetitia, n. 327.

37 Idem, n. 301. 
que vivem nesta situação, como se fossem pedras atiradas contra a vida das pessoas ${ }^{38}$.

Por causa de condicionamentos ou de fatores atenuantes, alguns dos quais aqui já mencionados, pode-se viver na graça de Deus, amar e também crescer na vida da graça e da caridade, recebendo para isso a ajuda da Igreja que inclui os sacramentos" ${ }^{39}$. "A Eucaristia não é um prêmio para os perfeitos, mas um remédio generoso e um alimento aos que necessitam" ${ }^{40}$. Por isso, quando numa situação particular não se verificar culpa grave $\mathrm{e}^{41}$, os sacerdotes que acompanham as pessoas interessadas pelo caminho do discernimento segundo a doutrina da Igreja e as orientações do bispo, depois dum exame de consciência através de momentos de reflexão e arrependimento ${ }^{42}$, não devem fechar as portas dos sacramentos ${ }^{43}$.

\section{A distinção entre uniões matrimoniais e uniões homoafetivas}

O parágrafo 52 de Amoris Laetitia afirma:

Já não se adverte claramente que só a união (1) exclusiva $e$ (2) indissolúvel entre um homem e uma mulher realiza uma (3) função social plena, por ser um (4) compromisso estável e tornar (5) possível a fecundidade. Devemos reconhecer a grande variedade de situações familiares que podem fornecer certa regra de vida, mas as uniões de fato ou entre pessoas do mesmo sexo, por exemplo, não podem ser simplistamente equiparadas ao matrimônio ${ }^{44}$.

Esse trecho do parágrafo 52 da exortação pós-sinodal possui diversos elementos dignos de um olhar mais atento. No que se refere especificamente às uniões homoafetivas, o papa afirma que estas "não podem ser simplistamente equiparadas ao matrimônio". Sobre essa equiparação, Francisco ainda registra:

\footnotetext{
38 Cf. Idem, n. 305.

Cf. Ibidem.

Evangelii Gaudium, n. 47.

Cf. nota 336 de Amoris Laetitia, n. 300.

Cf. Amoris Laetitia, n. 300.

Cf. Evangelii Gaudium, n. 47.

44 Amoris Laetitia, n. 52 (grifos e numeração nossas).
} 
No decurso dos debates sobre a dignidade e a missão da família, os Padres sinodais anotaram, quanto aos projetos de equiparação ao matrimônio das uniões entre pessoas homossexuais, que não existe fundamento algum para assimilar ou estabelecer analogias, nem sequer remotas, entre as uniões homossexuais e o desígnio de Deus sobre o matrimônio e a família ${ }^{45}$.

Com efeito, a Igreja ensina que não existe matrimônio entre pessoas do mesmo sexo, pois o matrimônio é a união entre um homem e uma mulher. As uniões homoafetivas possuem características que a diferenciam de um matrimônio. Nesse sentido, faz-se necessário identificar as especificidades dessas uniões, dada a sua atual relevância enquanto fenômeno social. Para fazer essa investigação, é preciso contrastá-las com as uniões matrimoniais, não para equipará-las nem tão pouco para criar analogias entre elas ${ }^{46}$. Mas, justamente para constatar o que é específico da experiência de uma união homossexual.

Como vimos acima, na citação do parágrafo 52 da exortação Amoris Laetitia, o papa caracteriza uma união matrimonial como (1) exclusiva e (2) indissolúvel, realizadora de uma (3) função social plena, (4) compromisso estável e que torna (5) possivel a fecundidade. Queremos nos deter por um momento em cada um desses elementos constitutivos de uma união entre um homem e uma mulher, confrontando-os à situação das uniões homossexuais para daí colher pistas para uma identidade específica destas últimas. Mesmo que não se equiparem ao matrimônio, são reconhecidos valores positivos nas uniões homoafetivas.

Os matrimônios se constituem como união (2) indissolúvel porque "a união matrimonial entre o homem e a mulher foi elevada por Cristo à dignidade de sacramento" ${ }^{47}$, ao passo que as uniões entre pessoas do mesmo sexo são de outra natureza. Contudo, elas podem apresentar, a seu modo, características de (1) exclusividade e de (4) compromisso estável na medida em que as pessoas implicadas nessas uniões cultivam uma fidelidade recíproca e uma união duradoura.

45 Idem, n. 251; Cf. CONGREGAÇÃO PARA A DOUTRINA DA FÉ. Considerações sobre os projetos de reconhecimento legal das uniões entre pessoas homossexuais, 2003. n. 4. Disponível em: <http://www.vatican.va/roman_curia/congregations/cfaith/ documents/rc_con_cfaith_doc_20030731_homosexual-unions_po.html>.Acesso em: 02 jul. 2019.

46 Cf. Considerações sobre os projetos de reconhecimento legal das uniões entre pessoas homossexuais, n. 8.

47 Idem, n. 3. 
A Carta aos Romanos 1,23-27 nos ajuda a entrever essa possibilidade precisamente quando nos apresenta uma situação social de atividade homossexual em que não há uniões entre pessoas do mesmo sexo. Nesse trecho da Epístola aos Romanos, São Paulo reprova a prática da homossexualidade porque ela está vinculada à idolatria e à infidelidade a Deus: "Trocaram a glória do Deus incorruptível por imagens de homens corruptíveis, de aves, quadrúpedes e répteis" $(1,23)$. O Apóstolo dos gentios registra nesse trecho sua reprovação aos costumes pagãos contrários à fé cristã que o povo insiste em praticar. Daí que as pessoas estão entregues "a seus desejos imundos, que degradam os seus próprios corpos" $(1,24)$ por consequência da sua prática idolátrica e de infidelidade a Deus. Portanto, a censura de São Paulo se refere primeiramente à infidelidade e idolatria do povo. Ele critica os antigos costumes pagãos que, inclusive, de acordo com a descrição de Romanos 1,26-27, envolviam atos sexuais homossexuais. Tais atos são descritos como praticados por mulheres e homens que possivelmente mantinham algum vínculo afetivo e sexual com pessoas do sexo oposto, pois o texto bíblico afirma que "deixaram a relação natural" $(1,27)$ para praticarem relações homossexuais. Ora, tal descrição em nada se assemelha a uma união homoafetiva (1) exclusiva e (4) estável, antes, parece descrever uma prática homossexual idolátrica, promíscua e descompromissada de pessoas que mantinham relações sexuais com mulheres e homens e que trocaram a sua fé em Deus por práticas pagãs (cf. Rm 1,25). Sendo assim, não é possível aplicar esse trecho bíblico às diversas pessoas homossexuais cristãs que vivem uma união com pessoas do mesmo sexo e que, ao contrário dos descritos na Carta aos Romanos, buscam a Deus com sinceridade na Igreja. Da mesma forma, é igualmente impossível inferir que todas as pessoas homossexuais estejam envoltas em relações sexuais promíscuas, idolátricas e descompromissadas.

\section{A função social parcial das uniões homoafetivas}

As uniões homossexuais que são exclusivas e fundadas na fidelidade recíproca não são totalmente desprovidas de alguma função social, embora não realizam uma (3) função social plena. Elas parecem realizar a seu modo uma função social parcial visto que compõem inegavelmente a variedade de situações familiares que existem hoje e que "podem 
fornecer certa regra de vida"48. Sua função social é parcial porque não realizam aquilo que é próprio das uniões matrimoniais.

É bem verdade que a Congregação para a Doutrina da Fé já asseverou que há "razões válidas para afirmar que tais uniões [homoafetivas] são nocivas a um reto progresso da sociedade humana, sobretudo se aumentasse a sua efetiva incidência sobre o tecido social" ${ }^{49}$. Ora, essa afirmação contida no texto Considerações Sobre Os Projetos De Reconhecimento Legal Das Uniões Entre Pessoas Homossexuais visa opor-se ao reconhecimento civil e equiparação das uniões entre pessoas do mesmo sexo com o matrimônio. Além disso, o texto recorda que a sociedade humana não poderia ser composta prioritária ou exclusivamente por uniões homoafetivas, uma vez que é papel social da união matrimonial transmitir a vida ${ }^{50}$ de modo a garantir o "reto progresso da sociedade humana". De fato, "nenhuma união precária ou fechada à transmissão da vida garante o futuro da sociedade" ${ }^{1}$. Contudo, isso "não quer dizer que as pessoas homossexuais não sejam frequentemente generosas e não se doem" 52 .

Ao longo da história da humanidade, o fenômeno da homossexualidade fez-se presente nas sociedades de diferentes maneiras. Ele "tem-se revestido de formas muito variadas, através dos séculos e das culturas" ${ }^{53}$, perpassando os distintos tecidos sociais. De alguma maneira, o fenômeno da homossexualidade que sempre esteve presente nas sociedades se revestiu de papéis sociais diferentes ao longo do tempo.

Os papéis sociais que um matrimônio e uma união homoafetiva podem desempenhar são distintos. O matrimônio desempenha uma função social plena, enquanto as uniões homoafetivas podem desempenhar, a seu modo, uma função social parcial. Com efeito, um relatório preliminar

48 Amoris Laetitia, n. 52.

49 Considerações sobre os projetos de reconhecimento legal das uniões entre pessoas homossexuais, n. 3.

50 "Porque os casais matrimoniais têm a função de garantir a ordem das gerações e, portanto, são de relevante interesse público, o direito civil confere-lhes um reconhecimento institucional. As uniões homossexuais, invés, não exigem uma específica atenção por parte do ordenamento jurídico, porque não desempenham essa função em ordem ao bem comum". Considerações Sobre Os Projetos De Reconhecimento Legal Das Uniões Entre Pessoas Homossexuais, n. 9.

51 Amoris Laetitia, n. 52.

52 Carta aos bispos da Igreja Católica sobre o atendimento pastoral das pessoas homossexuais, n. 7.

53 Catecismo da Igreja Católica, n. 2357. 
do sínodo dos bispos de 2014 afirma que "sem negar as problemáticas morais ligadas às uniões homossexuais, tomamos consciência de que há casos nos quais o apoio recíproco até ao sacrifício constitui um apoio precioso para a vida dos parceiros" ${ }^{24}$. O texto aponta que há casos em que os/as parceiros/as de uma união homossexual expressam um "apoio recíproco", isto é, uma doação mútua que pode chegar até ao "sacrifício" desinteressado. Isso indica, portanto, que tal união cumpre uma função social primeiramente na vida dos/as parceiros/as que são beneficiados/ as pelo recíproco "apoio precioso para a vida".

Ora, esse "apoio precioso para a vida" pode ser caracterizado como uma espécie de apreço amoroso, "não o amor da concupiscência, que vê só objetos com que satisfazer os próprios apetites, mas o amor de amizade e oblatividade, capaz de reconhecer e amar as pessoas por si mesmas. É um amor capaz de generosidade, à semelhança do amor de Deus" ${ }^{55}$, como na parábola do samaritano (cf. Lc 10,30-37), em que o cuidado com o/a outro/a que é diferente, mas ao mesmo tempo tão igual, é expressão de amor e apreço, sinal do amor de Deus. "É um amor que gera a comunhão entre as pessoas, visto que cada um considera o bem do outro como próprio. É um dom de si feito àquele que se ama, no qual se descobre, se atua a própria bondade na comunhão de pessoas e se aprende o valor de ser amado e de amar" ${ }^{56}$. Nesse sentido, "o amor é verdadeiro, quando cria o bem das pessoas e das comunidades, cria e dá-lo aos outros" ${ }^{57}$. É precisamente a partir do verdadeiro apreço mútuo que se estende efetivamente a função social parcial que se realiza quando "cria o bem das pessoas e das comunidades".

Desse modo, não é possível afirmar que o "apoio recíproco" para "a vida dos parceiros" seja a única função social que uma união entre pessoas do mesmo sexo possa desempenhar. Em Amoris Laetitia, o papa Francisco disse que "na perspectiva da pedagogia divina, a Igreja olha com amor para aqueles que participam de modo imperfeito na vida dela: com eles, invoca a graça da conversão; encoraja-os a fazerem o bem, a

$54 \quad$ Relatio post disceptationem, n. 52.

55 CONSELHO PONTIFÍCIO PARAA FAMÍLIA. Sexualidade Humana: Verdade e Significado, 1995. n. 9. Disponível em: <http://www.vatican.va/roman_curia/pontifical_councils/family/documents/rc_pc_family_doc_08121995_human-sexuality_po.html>. Acesso em: 02 jul. 2019. Ibidem.

57 SÃO JOÃO PAULO II, papa. Carta às Famílias Gratissimam Sane, 1994. n. 14 Disponível em: <https://w2.vatican.va/content/john-paul-ii/pt/letters/1994/documents/ hf_jp-ii_let_02021994_families.html>. Acesso em: 02 jul. 2019. 
cuidarem com amor um do outro e colocarem-se ao serviço da comunidade onde vivem e trabalham" 58 ; e acrescenta que "os batizados que se divorciaram e voltaram a casar civilmente devem ser mais integrados na comunidade cristã sob as diferentes formas possíveis, evitando toda a ocasião de escândalo" e "não só aos divorciados que vivem numa nova união, mas a todos seja qual for a situação em que se encontrem" $"$. Dito de outra maneira, a comunidade cristã é lugar favorável para a acolhida e integração de "todos, seja qual for a situação em que se encontrem", e isso inclui certamente as pessoas que vivem uniões homoafetivas, de modo a levá-las a compreender que são chamadas a uma função social parcial que também consiste em "fazer o bem", "colocando-se ao serviço da comunidade onde vivem e trabalham".

\section{Fecundidade alargada}

Das características elencadas a partir do parágrafo 52 da exortação Apostólica Amoris Laetitia, falta tratar da última, a (5) fecundidade. Só é possível falar em fecundidade de uniões homoafetivas a partir de um alargamento da categoria fecundidade, na esteira daquilo que nos propõe o papa Francisco nos números 178-184 da exortação apostólica sobre o amor na família. Com efeito, falar em fecundidade de uniões entre pessoas do mesmo sexo não é o mesmo que falar em fecundidade matrimonial. A fecundidade de um matrimônio é essencialmente a capacidade de procriação e educação da prole. A possível fecundidade de uma união precária do ponto de vista de transmissão da vida, vincula-se à dimensão de alargamento da categoria fecundidade, descortinada na exortação Amoris Laetitia.

Uniões entre pessoas do mesmo sexo não gozam da fecundidade própria de uma união matrimonial porque são fechadas à transmissão da vida, por isso incapazes de garantir o futuro da sociedade, e a adoção de crianças por casais do mesmo sexo não garante o desenvolvimento integral da criança ${ }^{60}$. Todavia, o papa Francisco disse que “convém

58 Amoris Laetitia, n. 78; 291.

59 Idem, n. 297 (grifos nossos).

60 "Como a experiência confirma, a falta da bipolaridade sexual cria obstáculos ao desenvolvimento normal das crianças eventualmente inseridas no interior dessas uniões. Falta-Ihes, de facto, a experiência da maternidade ou paternidade. Inserir crianças nas uniões homossexuais através da adoção significa, na realidade, praticar a violência sobre essas crianças, no sentido que se aproveita do seu estado de fraqueza para 
lembrar-nos também de que a procriação e a adoção não são as únicas maneiras de viver a fecundidade do amor" ${ }^{\prime \prime}$.

Em primeiro lugar, é preciso afirmar que "a pessoa humana, criada à imagem e semelhança de Deus, não pode definir-se cabalmente por uma simples e redutiva referência à sua orientação sexual". As pessoas são muito mais do que a sua orientação sexual. É fato que "toda e qualquer pessoa que vive sobre a face da terra conhece problemas e dificuldades pessoais, mas possui também oportunidades de crescimento, recursos, talentos e dons próprios" ${ }^{62}$. Portanto, também "as pessoas homossexuais têm dons e qualidades para oferecer à comunidade cristã" ${ }^{\prime}$, ainda mais se considerarmos que as pessoas homossexuais batizadas são uma parcela do Povo de Deus. Esses dons que elas possuem edificam a Igreja, como nos ensina São Paulo quando compara o povo de Deus a um corpo humano (cf. I Cor 12,1427). Cada parte do corpo é importante: a mão, o olho, o pé. Basta considerar os dons trazidos por pessoas homossexuais que atuam em paróquias, escolas, universidades, pastorais, movimentos, hospitais e instituições de serviços sociais católicas. Seus dons são marcas positivas deixadas na sociedade onde estão inseridas, desenvolvendo outras formas de fecundidade que são uma espécie de extensão do amor que as sustenta ${ }^{64}$.

Não raras vezes, as pessoas homossexuais têm suportado, desde cedo, preconceitos, ódio, perseguição e até mesmo agressões e violência:

É de se deplorar firmemente que as pessoas homossexuais tenham sido e sejam ainda hoje objeto de expressões malévolas e de ações violentas.

introduzi-las em ambientes que não favorecem o seu pleno desenvolvimento humano. Não há dúvida que uma tal prática seria gravemente imoral e pôr-se-ia em aberta contradição com o princípio reconhecido também pela Convenção internacional da ONU sobre os direitos da criança, segundo o qual, o interesse superior a tutelar é sempre o da criança, que é a parte mais fraca e indefesa". Considerações Sobre Os Projetos De Reconhecimento Legal Das Uniões Entre Pessoas Homossexuais, n. 7. Community can enter into a relationship of respect, compassion, and sensitivity. San Francisco: HarperOne, EPub Edition, ISBN 978-0-06-269434-8, 2017, p. 44-45; Cf. Amoris Laetitia, n. 181. 
Semelhantes comportamentos merecem a condenação dos pastores da Igreja, onde quer que aconteçam ${ }^{65}$.

"As pessoas homossexuais, como seres humanos, têm os mesmos direitos de todas as pessoas, inclusivamente o direito de não serem tratadas de maneira que ofenda a sua dignidade pessoal" ${ }^{66}$. Daí que muitas vezes elas sentem uma compaixão natural pelos que são marginalizados e essa compaixão é vivida como um dom fecundo em favor dos outros. Muitas vezes também, elas se sentiram e se sentem rejeitadas em comunidades paroquiais, mas perseveram por causa de sua vigorosa fé. E muitas vezes perdoaram o clero e outros membros da Igreja pela descriminação com que foram tratadas. A perseverança e o perdão que desenvolveram também são dons de alargada fecundidade ${ }^{67}$.

Com efeito, a possível fecundidade em uniões homoafetivas não se refere a uma natural fecundidade própria dessas uniões, mas à somatória dos dons, talentos e qualidades das duas pessoas homossexuais unidas em estreito vínculo afetivo, que são colocados a serviço do bem comum. Esse vínculo afetivo baseado numa união estável e exclusiva constitui-se como elemento capaz de facilitar a simbiose dos/as parceiros/as, de modo que melhor articulam seus dons em serviço dos outros ${ }^{68}$.

As pessoas em uniões homoafetivas também podem colocar seus dons a serviço dos demais através do anúncio explícito do Evangelho e do legado de múltiplas formas de testemunho, nomeadamente a solidariedade com os pobres, a abertura à diversidade das pessoas, a salvaguarda da criação, a solidariedade moral e material para com as pessoas em outras situações familiares, especialmente para com as mais necessitadas, o em-

65 Carta aos bispos da Igreja Católica sobre o atendimento pastoral das pessoas homossexuais, n. 10.

66 CONGREGAÇÃO PARAADOUTRINA DAFÉ. Algumas Reflexões acerca da Resposta a Propostas Legislativas Sobre a Não Discriminação Das Pessoas Homossexuais, 1992. n. 12. Disponível em: <http://www.vatican.va/roman_curia/congregations/cfaith/ documents/rc_con_cfaith_doc_19920724_homosexual-persons_po.html>.Acesso em 02 jul. 2019.

67 Cf. MARTIN, SJ, James. Building a Bridge: How the Catholic Church and the LBGT Community can enter into a relationship of respect, compassion, and sensitivity. San Francisco: HarperOne, EPub Edition, ISBN 978-0-06-269434-8, 2017. p. 12-13.

68 Os teólogos católicos 'revisionistas' do ensinamento oficial da Igreja, Lisa Cahill, Keane, Charles Curran e Richard McCormick endossam essa posição. Uma síntese de suas abordagens sobre esse tema pode ser vista em GENOVESI, SJ. Vicent. Em busca do amor: moralidade católica e sexualidade humana. São Paulo: Loyola, 2008. pp. 280-290. 
penho na promoção do bem comum, inclusive através da transformação das estruturas sociais injustas, a partir do território onde vivem, praticando as obras corporais e espirituais de misericórdia ${ }^{69}$. Sob o impulso do Espírito, abrem-se, saem de si para colocar seus dons e qualidades a serviço dos outros, para cuidar deles e procurar a sua felicidade ${ }^{70}$. Com efeito, a fecundidade alarga-se, traduzindo-se em mil e uma maneiras de tornar o amor de Deus presente na sociedade ${ }^{71}$.

De qualquer forma, o papa Francisco nos ensina que

em toda e qualquer circunstância, perante quem tenha dificuldade em viver plenamente a lei de Deus, deve ressoar o convite a percorrer a via caritatis. A caridade fraterna é a primeira lei dos cristãos (cf. Jo 15,12; Gal 5,14). Não esqueçamos a promessa feita na Sagrada Escritura: "Acima de tudo, mantende entre vós uma intensa caridade, porque o amor cobre a multidão de pecados" (1Pd 4,8); "redime o teu pecado pela justiça; e as tuas iniquidades, pela piedade para com os infelizes" (Dn 4,24); "a água apaga o fogo ardente, e a esmola expia o pecado" (Eclo 3,30) ${ }^{72}$.

A via caritatis é uma porta da misericórdia divina sempre aberta na Igreja. "O caminho da Igreja, desde o Concílio de Jerusalém em diante, é sempre o de Jesus: o caminho da misericórdia e da integração". A via caritatis é um caminho seguro de encontro com a misericórdia infinita do Pai. "O caminho da Igreja é o de não condenar eternamente ninguém; derramar a misericórdia de Deus sobre todas as pessoas que a pedem com coração sincero [...]. Porque a caridade verdadeira é sempre imerecida, incondicional e gratuita" 73 . O caminho da caridade fraterna é um caminho fecundo de doação e de serviço aos outros.

Desenvolvem a fecundidade alargada as uniões de pessoas do mesmo sexo que transmitem a fé cristã pelo anúncio do Evangelho, e

69 Cf. Amoris Laetitia, n. 290. "As obras de misericórdia são as ações caridosas pelas quais vamos em ajuda do nosso próximo, nas suas necessidades corporais e espirituais. Instruir, aconselhar, consolar, confortar, são obras de misericórdia espirituais, como perdoar e suportar com paciência. As obras de misericórdia corporais consistem nomeadamente em dar de comer a quem tem fome, albergar quem não tem teto, vestir os nus, visitar os doentes e os presos, sepultar os mortos" (Catecismo da Igreja Católica, n. 2447).

Cf. Amoris Laetitia, n. 324.

Cf. Idem, n. 184.

Idem, n. 296. 
testemunham a fraternidade, a sensibilidade social e a defesa das pessoas mais frágeis ${ }^{74}$.

\section{Considerações finais}

Muitas vezes as pessoas em uniões homoafetivas desejam encontrar uma Igreja que seja casa acolhedora. São pessoas cristãs, parcela do povo de Deus, que buscam participar ativamente da vida e da missão da Igreja. Por essa razão, torna-se necessário uma reflexão de caminhos de integração dessas pessoas à comunidade cristã. Para isso, é preciso aprofundar os elementos da tradição de fé e doutrina da Igreja que possam ajudar na revisão da situação moral dessas uniões, a partir de um acompanhamento caso a caso.

A misericórdia infinita do Pai que é dispensada e oferecida pela Igreja não compactua com a lógica da condenação. $\mathrm{O}$ amor salvador de Deus liberta as pessoas das amarras do pecado, e lhes tira o pesado fardo da culpabilidade de ações sob as quais não possuem deliberalidade. Essa ação libertadora de Deus precisa ser explicitamente anunciada pela Igreja e oferecida a todos/as, sobretudo aos que se encontram em situações familiares desafiadoras.

As uniões entre pessoas do mesmo sexo são um fenômeno social público com características próprias que precisam ser também consideradas pela Igreja. Elas possuem elementos positivos que são caracterizados como expressão da fecundidade das pessoas implicadas nessas uniões.

\section{Bibliografia}

BESSON, Claude. Homossexuais católicos: como sair do impasse. São Paulo: Loyola, 2015.

CATECISMO DA IGREJA CATÓLICA (CaIC), 1991. Disponível em: <http://www.vatican.va/archive/cathechism_po/index_new/prima-pagina-cic_po.html>. Acesso em: 02 jul. 2019.

CONGREGAÇÃO PARA A DOUTRINA DA FÉ. Algumas Reflexões acerca da Resposta a Propostas Legislativas Sobre a Não Discriminação Das Pessoas Homossexuais, 1992. Disponível em: <http://www.

$74 \quad$ Cf. Idem, n.184. 
vatican.va/roman_curia/congregations/cfaith/documents/rc_con_cfaith doc_19920724_homosexual-persons_po.html >. Acesso em: 02 jul. 2019.

. Carta aos bispos da Igreja Católica sobre o atendimento pastoral das pessoas homossexuais, 1986. Disponível em: <http://www. vatican.va/roman_curia/congregations/cfaith/documents/rc_con_cfaith doc_19861001_homosexual-persons_po.html >. Acesso em: 02 jul. 2019.

. Considerações sobre os projetos de reconhecimento legal das uniões entre pessoas homossexuais, 2003. Disponível em: <http://www. vatican.va/roman_curia/congregations/cfaith/documents/rc_con_cfaith doc_20030731_homosexual-unions_po.html>.Acesso em: 02 jul. 2019.

The Moral Norm Of "Humanae Vitae" And Pastoral Duty, 1989. Disponível em: $<$ http://www.vatican.va/roman_curia/congregations/cfaith/documents/rc_con_cfaith_doc_19890216_norma-morale_en.html $>$. Acesso em: 02 jul. 2019.

CONSELHO FEDERAL DE PSICOLOGIA. Resolução CFP $n^{\circ}$ 001/99 de 22 de março de 1999: Estabelece normas de atuação para os psicólogos em relação à questão da Orientação Sexual, Brasília, 1999. Disponível em: <https://site.cfp.org.br/wp-content/uploads/1999/03/ resolucao1999_1.pdf >. Acesso em: 02 jul. 2019.

CONSELHO PONTIFÍCIO PARA A FAMÍLIA. Sexualidade Humana: Verdade e Significado, 1995. Disponível em: <http://www.vatican. va/roman_curia/pontifical_councils/family/documents/rc_pc_family_doc_08121995_human-sexuality_po.html >. Acesso em: 02 jul. 2019.

FRANCISCO, Papa. Exortação Apostólica Evangelii Gaudium (EG),2013. Disponível em: <https://w2.vatican.va/content/francesco/pt/apost_exhortations/documents/papa-francesco_esortazione-ap_20131124_evangelii-gaudium.html>. Acesso em: 02 jul. 2019.

. Exortação apostólica pós-sinodal Amoris Laetitia (AL), 2016. Disponível em: $<$ http://w2.vatican.va/content/francesco/pt/apost_exhortations/documents/papa-francesco_esortazione-ap_20160319_amoris-laetitia.html>. Acesso em: 02 jul. 2019.

GENOVESI, SJ. Vicent. Em busca do amor: moralidade católica e sexualidade humana, São Paulo: Loyola, 2008.

III ASSEMBLEIA GERAL EXTRAORDINÁRIA DO SÍNODO DOS BISPOS. Relatio post disceptationem, 2014. Disponível em: $<$ http://www. 
vatican.va/roman_curia/synod/documents/rc_synod_doc_20141013_erdo-synod_po.html >. Acesso em: 02 jul. 2019.

MARTIN, SJ, James. Building a Bridge: How the Catholic Church and the LBGT Community can enter into a relationship of respect, compassion, and sensitivity. San Francisco: HarperOne, EPub Edition, ISBN 978-0-06-269434-8, 2017.

SÃO JOÃO PAULO II, Papa. Carta às Famílias Gratissimam Sane, 1994. Disponível em: <https://w2.vatican.va/content/john-paul-ii/pt/ letters/1994/documents/hf_jp-ii_let_02021994_families.html>. Acesso em: 02 jul. 2019.

. Exortação Apostólica Familiaris Consortio (FC), 1981. Disponível em: <http://w2.vatican.va/content/john-paul-ii/pt/apost_exhortations/ documents/hf_jp-ii_exh_19811122_familiaris-consortio.html $>$. Acesso em: 02 jul. 2019.

XV ASSEMBLEIA GERAL ORDINÁRIA DO SÍNODO DOS BISPOS. Instrumentum Laboris, 2018. Disponível em: $<$ http://www.vatican. va/roman_curia/synod/documents/rc_synod_doc_20180508_instrumentum-xvassemblea-giovani_po.html>. Acesso em: 02 jul. 2019. 